\title{
TABLE OF STATUTORY INSTRUMENTS
}

1993 Act of Sederunt (Sheriff Court Ordinary Cause Rules) (SI 1993/1956)

1999 Act of Sederunt (Summary Applications, Statutory Applications and

Appeals etc) Rules (SI 1999/929)

$$
\text { r } 3.35 .3 .
$$

$64,71,85$

(1)

(2)

(3)

r 3.35.4

r 3.35 .5

Sch 1, Form 34

Form 35.

86,111

2007 Justices of the Peace (Scotland) Order (SSI 2007/210)..... 73

2008 Act of Sederunt (Summary Applications, Statutory Applications and

Appeals etc Rules) Amendment (Adult Support and Protection (Scotland) Act 2007) (No 2) (SSI 2008/335)

para 2 .

(2)

Act of Sederunt (Summary Applications, Statutory Applications and

Appeals etc Rules) Amendment (Adult Support and Protection

(Scotland) Act 2007) (No 3) (SSI 2008/375).....

para 2(3)

Adult Support and Protection (Scotland) Act 2007 (Restriction on the

Authorisation of Council Officers) Order (SSI 2008/306)

Adults with Incapacity (Accounts and Funds) (Scotland) Regulations

(SSI 2008/51)

2009 Justice of the Peace Courts (Sheriffdom of South Strathclyde, Dumfries and

Galloway) Order (SSI 2009/115). 
